\title{
Engineering and economic analysis of the production of sieve shaker for teaching particle size to students with visual impairment
}

\author{
Rina Maryanti*, Asep Bayu Dani Nandiyanto**, Achmad Hufad*, S. Sunardi*, \\ Risti Ragadhita**, Meli Fiandini** and Muhammad Roil Bilad*** \\ * Departement Pendidikan Khusus, Universitas Pendidikan Indonesia, Bandung, Indonesia \\ ** Departement Kimia, Universitas Pendidikan Indonesia, Bandung, Indonesia. \\ *** Departement of Chemical Engineering, Universiti Teknologi Petronas, Malaysia \\ **Corresponding Author: nandiyanto@upi.edu
}

Submitted : 31/03/2020

Revised : 20/05/2021

Accepted : 30/05/2021

\begin{abstract}
The purpose of this study was to evaluate the feasibility study in the production of sieve shaker for teaching particle size to students with visual impairment. The sieve shaker is important as a tool for understanding the definition of particles and their sizes, while this equipment has been well developed for engineering purposes. Different from other sieve shakers that are expensive, the present sieve shaker is just for educational goals only (especially for being used in developing countries), making the design of this equipment simpler, user friendlier, and more portable. The feasibility study was done from the engineering and economic perspectives. Engineering analysis was performed based on a simple mass balance analysis, adding it to the calculation of scale-up production from commercially available apparatuses. Economic evaluation was carried out using a number of economic parameters, including gross profit margin, payback period, and net profit value, in which all calculations were done under ideal and nonideal conditions (labor conditions, sales and raw materials, utilities, and external conditions and environmental uncertainties (competition, taxes and subsidiaries)) in 20 years (y) of project. All prices, utilizing components, and specifications for the apparatuses used in the scale-up production were taken based on the available online shopping web. The results of the engineering confirmed that the project was potentially conducted, even in small-scale industries because all processing steps could be carried out using simple equipment that is commercially available in the market. Economic evaluation results showed positive values for all economic parameters with a few exceptions. This research was complemented by some basic theories to support the definition of sieve shaker.
\end{abstract}

Keywords: Economic analysis; Economic parameters; Technical evaluation; Sieve shaker; Students with visual impairment; Education.

\section{INTRODUCTION}

Strategies for evaluating particle sizes have been well documented and well applied in industries and laboratories (both in schools and universities). Many apparatuses have been used, and one of the famous particle seizers is sieve 
test (Hierl et al., 2019). The sieve test analysis is effective in filtering the sizes based on its pore. Detailed information about sieve test is shown in

Figure 1.

Although the sieve analysis is effective in distinguishing particle size, problems in the usage of this apparatus are found, such as time-consuming analysis. To make it more efficient, the sieve test was supported with shaker machine. This combination is well known as sieve shaker equipment. The current sieve shaker equipment has been well applied in the field of engineering. However, this equipment is expensive. Sieve shaker is generally sold with costs ranging from 65 to more than 107 USD. Indeed, this is a problem for schools and universities in developing countries like Indonesia because they cannot afford expensive equipment (Berry et al., 2001). Therefore, research becomes important in producing simple, portable, and inexpensive equipment for scientific analysis, especially chemistry (Harris, 2008). Although many studies showed the effectiveness of the prototype sieve test analysis, they explained it only for limited use (Qi et al., 2017). Furthermore, there is no information on economic evaluation of the feasibility for commercial scale.

In our previous studies (Nandiyanto et al., 2016; Nandiyanto et al., 2017; Nandiyanto \& Ragadhita, 2019; Nurdiana et al., 2022; Elia et al., 2023), we have applied the feasibility studies for the production of several materials from engineering perspective with economic evaluation. Here, the purpose of this study was to evaluate the feasibility of the production of sieve shaker for educational purpose.
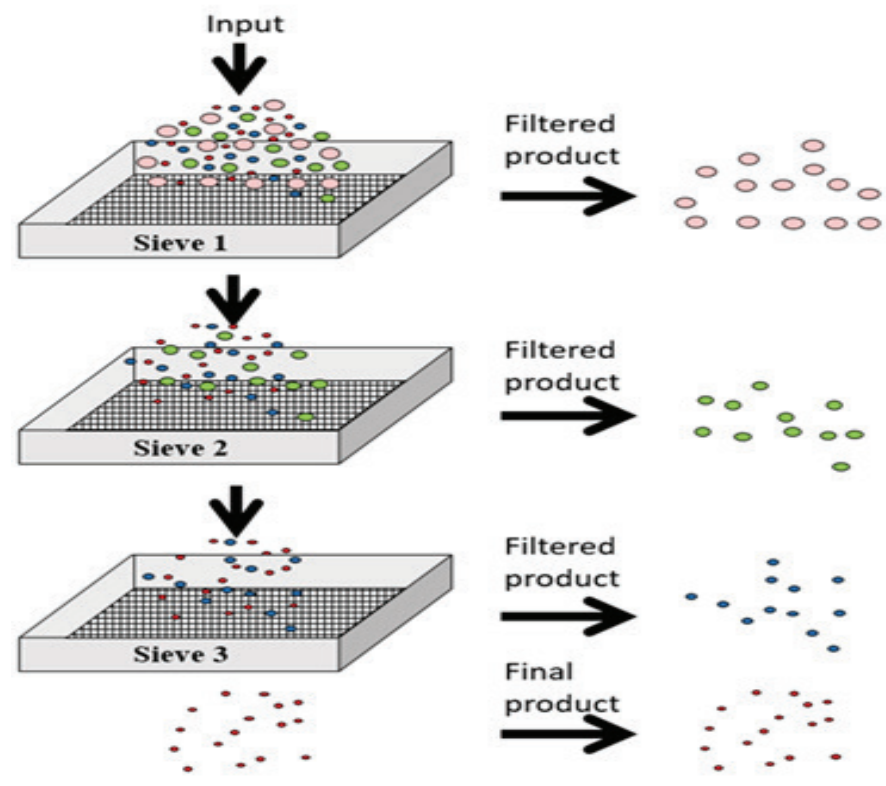

Figure 1. The principle of sieve test analysis.

The main ideas for the need in the production of this equipment are due to the limitations method for teaching the definition of particle sizes to students. Specifically, with this equipment, the definition of the particle size can be well taught to students with visual impairment. Students with visual impairments are students with special needs who have problems with their sense of sight. They have the characteristic of having difficulty understanding something abstract and complex (Maryanti et al., 2021a). These characteristics make students with visual impairments need special services and education. They learn through the auditory and tactile senses (Maryanti et al., 2020a). In order for the learning process to run effectively, learning media must be tailored to the needs of students (Rusyani et al., 
2021). One of them is understanding the particle size of the material. Students with visual impairments need innovation from existing sieve test tools. The innovative use of an automatic sieve test using a machine and equipped with braille makes it easier for students with visual impairments to understand and distinguish particle sizes. In short, the present sieve shaker was equipped with a combination of batteries and a 3-volt (V) dynamo, making it easy to be used, versatile, and inexpensive (Guarnieri, 2018).

Based on our previous reports on the feasibility study (Nandiyanto \& Ragadhita, 2019; Nurdiana et al., 2022; Elia et al., 2023), we compared the analysis from the ideal conditions to the nonideal conditions (labor conditions, sales and raw materials, utilities, and external conditions and environmental uncertainties (competition, taxes, and subsidiaries)). Engineering analysis was done based on the mass balance, whereas economic analysis was to get various parameters, including gross margin (GPM), internal rate of return (IRR), return period (PBP), cumulative net present value (CNPV), breakeven point (BEP), and profitability index (PI). All calculations were carried out under conditions for $20 \mathrm{y}$ of production. In addition, we complement the basic information introduction research that is sieve shaker to make readers understand and provide further developments.

\section{MATERIAL AND METHOD}

The illustration of the sieve shaker is shown in Figure 2. Figure 2 explains that the sieve shaker consists of two parts. In the first part, the sieve shaker consisted of 4 sieve containers equipped with 4 sieve filters, 4 braille plates to label the sieve size, 2 safety plates, and 2 iron hasps. The second (s) part is a sieve-shaped sieve holder made of acrylic called an acrylic stand, cable, dynamo, battery, and power button.

The experiments were carried out in the engineering perspective and economic evaluation (Nandiyanto et al., 2017). Engineering analysis was calculated using a simple mass balance analysis, while economic evaluations are carried out using several economic parameters, including GPM, IRR, PBP, CNPV, BEP, and PI sales for investment. In the economic analysis, all calculations are carried out and compared to the current economic engineering theories, in which this is well explained in the literature (Garrettt, 2012). To support analysis, prices, components, and equipment specifications, as well as raw materials, were taken based on the available online shopping web. All calculations are carried out under ideal and nonideal conditions for $20 \mathrm{y}$ of project. We also neglected either inflation or deflation during the project.

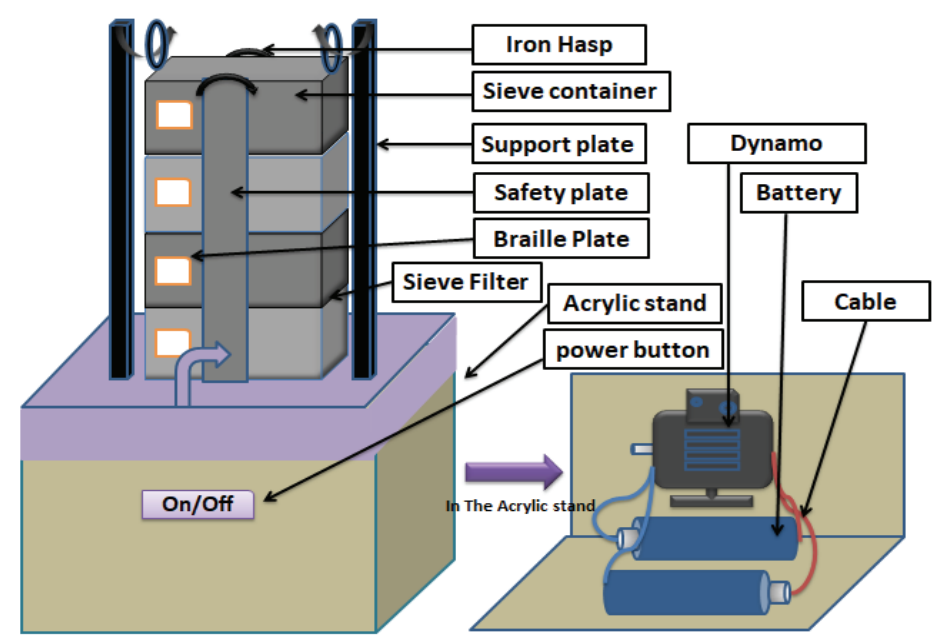

Figure 2. Illustration of sieve shaker. 
In the engineering analysis, the mass balance calculations were assumed:

a. Equipment was adopted and developed from the existing equipment.

b. The production cycle is around 2 hours (h) per equipment.

c. Working h per day (d) were from 8.00 to 16.00 ; or working h were $8 \mathrm{~h} / \mathrm{d}$.

d. One y contained $300 \mathrm{~d}$ of production, while the rest is day-off and preparation.

e. The project operation length was $20 \mathrm{y}$.

f. All costs were calculated based on ideal conditions that were no economic fluctuations (either inflation or deflation) for labor and utility costs, as well as raw materials and selling prices. All costs were stable during project operation.

g. Equipment prices were determined based on commercially available prices (Table 1). The Lang factor was used to analyze total factory costs (TPC) (Table 2) and total investment costs (TIC) (Table 3) (Garrettt, 2012).

h. Labor wages were 21.43 USD/d ( $=535.71 \mathrm{USD} / \mathrm{month}=6,428.57 \mathrm{USD} / \mathrm{y})$, and production employed 5 workers.

i. The basic cost of electricity was assumed to be 2.46 USD per kWh (Nandiyanto, 2018). The utility was only for most electricity (Nandiyanto et al., 2018), assumed to be $100 \mathrm{~W}$ for soldering (with a usage time of $8 \mathrm{~h} 20 \mathrm{~min} / \mathrm{d}$ ), $35 \mathrm{~W}$ for refining iron (with a usage time of $5 \mathrm{~h} / \mathrm{d}$ ), $30 \mathrm{~W}$ for cutters iron (with a usage time of $1.2 \mathrm{~h} / \mathrm{d}$ ), and $835 \mathrm{~W}$ for other purposes (with utility h of work $8 \mathrm{~h} / \mathrm{d}$ ).

j. The annual discount rate was $15 \%$. The discount rate was adopted based on the interest rate charged on the commercial banks. In this study, the discount rate was taken to be more than the general interest rate in the commercial banks. This discount rate was used as the interest rate used in the calculation of cash flow analysis to determine the present value of future cash flows.

k. Annual income tax was $10 \%$ based on general tax in Indonesia.

1. The project did not take a loan from the bank.

$\mathrm{m}$. The selling price of the product was 57.14 USD per equipment.

n. All products were fully sold. There was no product loss because improper product quality or damaged/as well as no destroyed raw components were obtained. Indeed, there was no consideration of waste (waste is $0 \%$ ).

o. All analyses were conducted in USD with a conversion rate of 14,000 IDR per USD.

\section{RESULTS AND DISCUSSION}

\section{Economic Analysis}

Figure 2 illustrates the sieve shaker, consisting of four stainless-steel sieves (having a size of $4 \times 4 \mathrm{~cm}$ and thickness of $0.3 \mathrm{~cm}$ ) equipped with a micron nylon screen sieve (having a size of $4 \times 4 \mathrm{~cm}$ ), iron haps, two pieces of hand-held plate strips (to lock the four sieves), a beam-shaped holder (made of acrylic with a dynamo, cable, and two batteries equipped with an on/off button), and holder on top of the equipment equipped with two sieve support plates. Detailed components are shown in Table 1. The main part of the sieve apparatus is a stainless-steel container, equipped with a micron-sized nylon filter. The main difficult components are to equip each sieve with a size using embossed letters and to make them stand although the equipment is completed with electrical components to make the sieve working automatically.

Table 1 explains the price of the equipment used to create a sieve shaker. One sieve shaker required a capital of 18.78 USD, but there was additional production equipment that must be purchased for 142.86 USD. 
Table 1. Parts needed for designing a set of sieve shakers.

\begin{tabular}{|c|c|c|c|}
\hline No & Component & Quantity & Price in USD \\
\hline 1 & Dynamo $3 \mathrm{~V}$ & 1 & 0,53571429 \\
\hline 2 & Battery & 2 & 0,67857143 \\
\hline 3 & Cable & $(40 \mathrm{~cm})$ & 0,00421429 \\
\hline 4 & Power button & 1 & 0,35714286 \\
\hline 5 & Braille plate & 4 & 4,57142857 \\
\hline 6 & Safety plate & $2(10 \mathrm{~cm} \times 2)$ & 0,2175 \\
\hline 7 & Support plate & $2(10 \mathrm{~cm} \times 2)$ & 0,2175 \\
\hline 8 & Iron Hasp & 2 & 1,91807143 \\
\hline 9 & Bolt & 4 & 0,07142857 \\
\hline 10 & Acrylic stand & $1(23 \mathrm{~cm} \mathrm{x} 45.75 \mathrm{~cm})$ & 7,225 \\
\hline 11 & Sieve Container & $4(4 \times 4 \mathrm{~cm}$ - thickness 0,3$)$ & 1,41071429 \\
\hline 12 & Sieve Filter & $4(4 \times 4 \mathrm{~cm})$ & 1,42857143 \\
\hline 13 & Glue gun & 1 & 0,14285714 \\
\hline 14 & Production tools & 3 & 142,857143 \\
\hline & Total & & 161,635857 \\
\hline & $\begin{array}{l}\text { Total price of the device } \\
\text { (price total - Production Tools) }\end{array}$ & & 18,77871429 \\
\hline
\end{tabular}

Table 2 explains the total costs to be incurred by the factory to produce sieve tools. Thus, the data obtained that the total plant cost was 3,192.86 USD and plant cost (land) is 2,835.71 USD. 
Table 2. Calculation of total plant cost.

\begin{tabular}{|c|c|c|}
\hline Component & Factor & Cost (USD) \\
\hline Purchased Equipment & 1 & 714,29 \\
\hline Piping & 0,5 & 357,14 \\
\hline Electrical & 0,1 & 71,43 \\
\hline Instrumentation & 0,2 & 142,86 \\
\hline Utilities & 0,5 & 357,14 \\
\hline Foundations & 0,1 & 71,43 \\
\hline Insulations & 0,06 & 42,86 \\
\hline Painting, fireproofing, safety & 0,05 & 35,71 \\
\hline Yard Improvement & 0,08 & 57,14 \\
\hline Environmental & 0,2 & 142,86 \\
\hline Building & 0,08 & 57,14 \\
\hline Land & 0,5 & 357,14 \\
\hline Subtotal 1 & & $2.407,14$ \\
\hline Construction, engineering & 0,6 & 428,57 \\
\hline Contractors fee & 0,3 & 214,29 \\
\hline Contingency & 0,2 & 142,86 \\
\hline Subtotal 2 & & 785,71 \\
\hline Total Plant Cost & & $3.192,86$ \\
\hline Total Plant Cost (Land) & & $2.835,71$ \\
\hline
\end{tabular}


Table 3 explains the calculation of the total investment cost. We obtained data of 3171.43 USD for Total Plant Investment without land.

Table 3. Calculation of total investment cost total plant investment-land.

\begin{tabular}{|c|c|c|}
\hline Component & Factor & Cost (USD) \\
\hline Other Capital Requirements & & \\
\hline Off-site Facilities & 0,2 & 142,86 \\
\hline Plant start-up & 0,07 & 50,00 \\
\hline Working capital & 0,2 & 142,86 \\
\hline Total Plant Investment -land & & $3.171,43$ \\
\hline
\end{tabular}

Based on the above considerations, the calculation can be considered as follows:

a. The total number of sieve shakers made by 5 workers is 20 pieces of equipment per $\mathrm{d}$. Then, calculating the total sieve apparatus per y (multiplying with 300 production $\mathrm{d}$ ), the total number of sieve shakers is 6,000 devices.

b. Utility costs can be calculated by multiplying utility and working $\mathrm{h}$. The total utility used per $\mathrm{d}$ is around $835 \mathrm{~W} \times 8 \mathrm{~h}, 30 \mathrm{~W} \times 1.4 \mathrm{~h}, 35 \mathrm{~W} \times 5 \mathrm{~h}$, and $100 \mathrm{~W} \times 8.2 \mathrm{~h}$. The total power used is $23,000 \mathrm{Wh} / \mathrm{d}$. Adding a total of 300 working $\mathrm{d} / \mathrm{y}$ yields a total power of $6,900,000 \mathrm{Wh}(=6,900 \mathrm{kWh} / \mathrm{y})$. Then, the cost of utilities can reach $739.29 \mathrm{USD} / \mathrm{y}$.

c. The results show that TIC is relatively inexpensive because all processing steps are carried out using commercially available equipment in the market. The process can also be done as a home industry.

\section{Economic Analysis in the Ideal Condition}

The first economic analysis of this project showed great results. GPM is more than 27.81 USD $/ 20$ pcs per $\mathrm{d}$. By calculating one y's production, GPM can reach 8,571 USD/y. BEP is 220 pcs.

To ensure a realistic economic analysis, Figure 3 illustrates the economic evaluation of sieve production based on the CNPV curve. The curves were calculated using various production capacities $100 \%$ annually in ideal conditions. The ideal conditions are assumed to have stable conditions for variable and fixed costs, labor costs, utility costs, and also the prices of raw materials and products. In this figure, production capacity illustrates the conditions of sales and products. $100 \%$ of the production capacity responds that all products are well distributed and sold. In the ideal condition, the profit increases continuously for $20 \mathrm{y}$, promising for the project to be applied with PBP value of less than $3 \mathrm{y}$. 


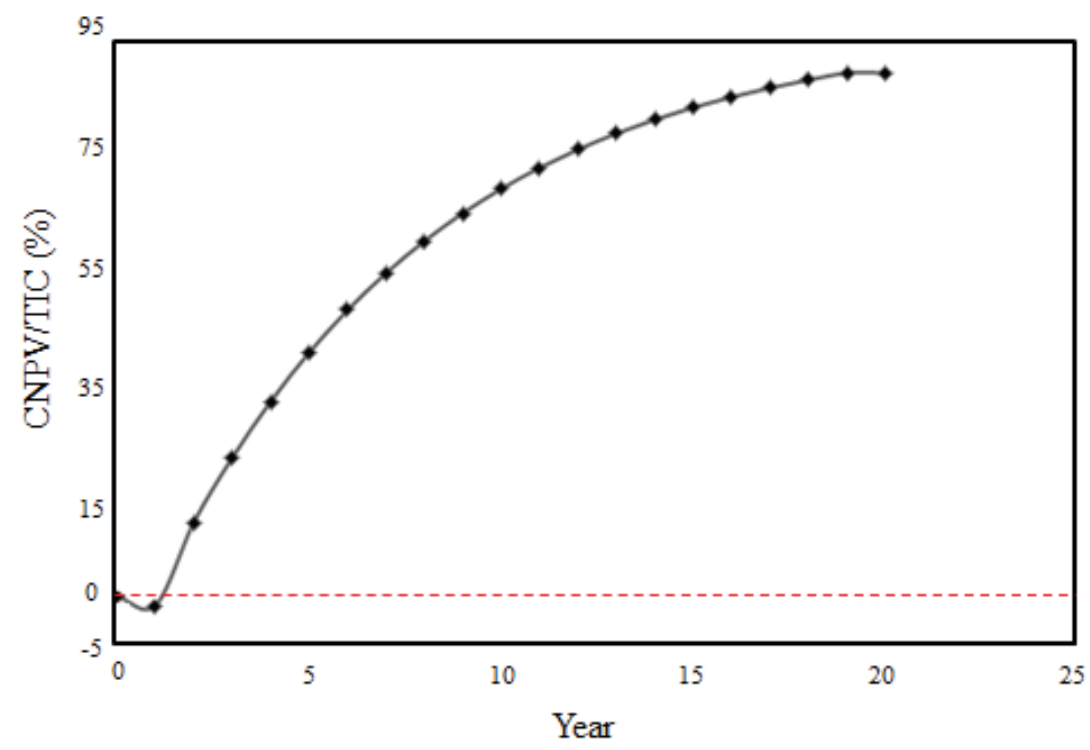

Figure 3. CNPV/TIC analysis of sieve shaker production under ideal condition.

\section{Economic Analysis as the Effect of Capacity Production on CNPV/TIC}

The analysis of the effect of production capacity shown by the CNPV/TIC curve is presented in Figure 4. The CNPV/TIC curve shows that decreasing production capacity causes profits to decline. Although the production capacity has decreased, the benefits obtained are still relatively large. However, a decrease in production capacity of less than $10 \%$ will cause the project to suffer losses.

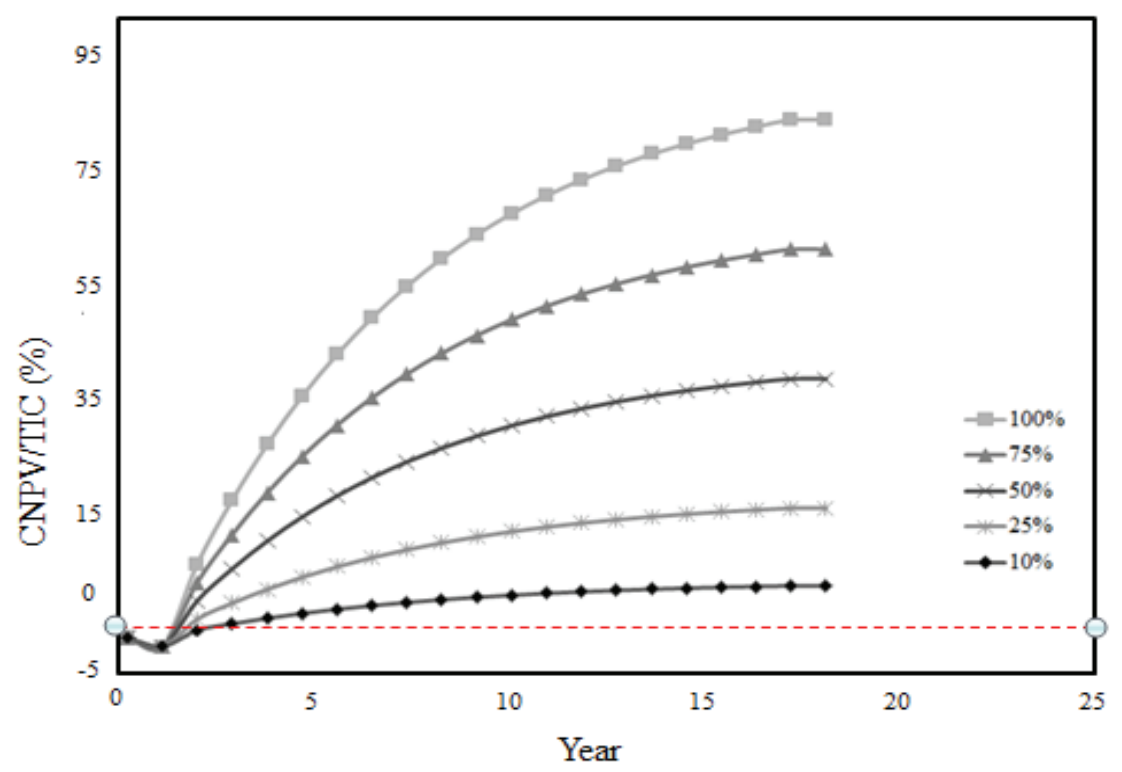

Figure 4. Effect of capacity production on CNPV/TIC. 


\section{Economic Analysis as the Effect of Taxes on CNPV/TIC}

The analysis of tax variations from the CNPV curve is shown in Figure 5. We also added an assumption that, in $0 \mathrm{y}$ until the first $\mathrm{y}$, the tax is not charged to the company because the company is still in the stage of project development. To determine the effect of tax on corporate income, speculation is carried out by changing taxes ranging from 10 to $85 \%$. The CNPV/TIC curve shows that the higher taxes imposed on companies can lead to getting lower profits. The effect of tax on CPNV/TIC can be seen after the first y. Even though the tax imposed is getting higher, the company still benefits from the production of sieve shaker.

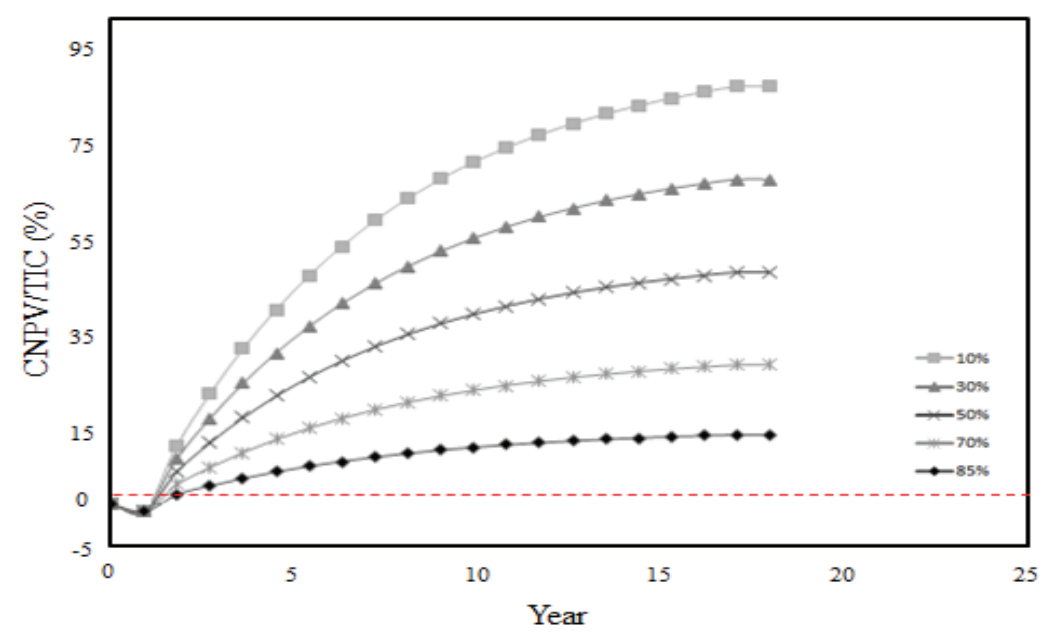

Figure 5. Effect of taxes on CNPV/TIC.

\section{Economic Analysis as the Effect of Variable Cost on CNPV/TIC}

Analysis of variations in the variable cost from the CNPV value is shown in Figure 6. Changes in variable costs are internal factors affecting the success of a project, such as the condition of raw materials, labor, and utilities. The $\mathrm{CNPV/TIC}$ curve shows that the change in variable cost does not influence profits significantly.

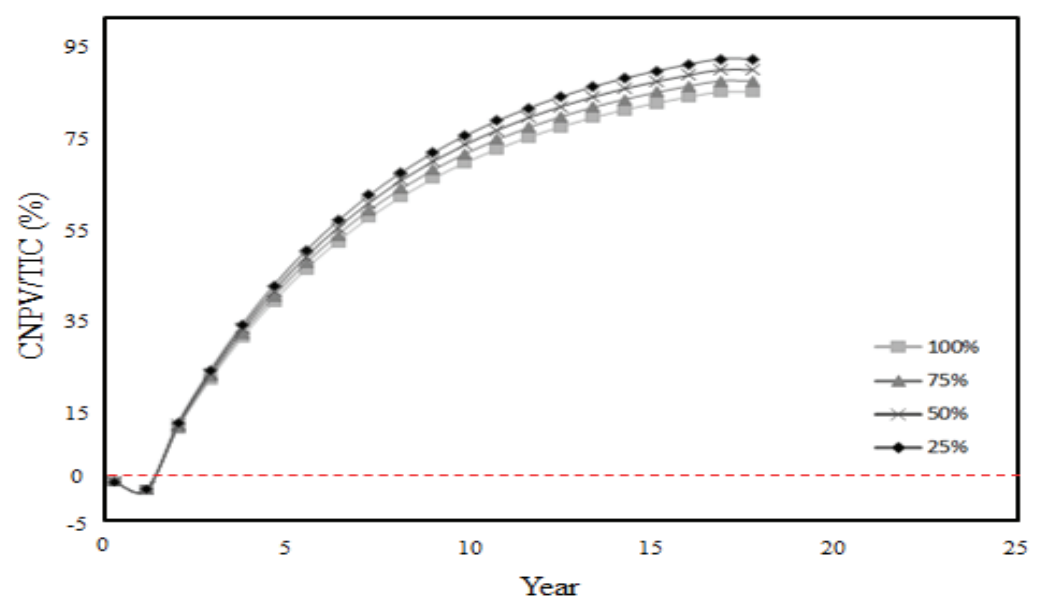

Figure 6. Effect of variable cost on CNPV/TIC. 


\section{Economic Analysis as the Effect of Sales to GPM}

Figure 7 is a curve of the effect of sales on the value of GPM. From this figure, the sensitivity of the estimated value (from -50 to $120 \%$ ) was made to see the effect of sales on GPM. The value of sales has a positive correlation with the GPM value. In short, a high sale value can increase the profit (GPM) of the project. In this project, the minimum profit can be achieved when the sales have a sensitivity of $25 \%$ of the estimated value of the sale. However, when the sensitivity of sales value is less than $25 \%$ (from estimated sales value), the project may fail. When we increased sales, the project can get more GPM.

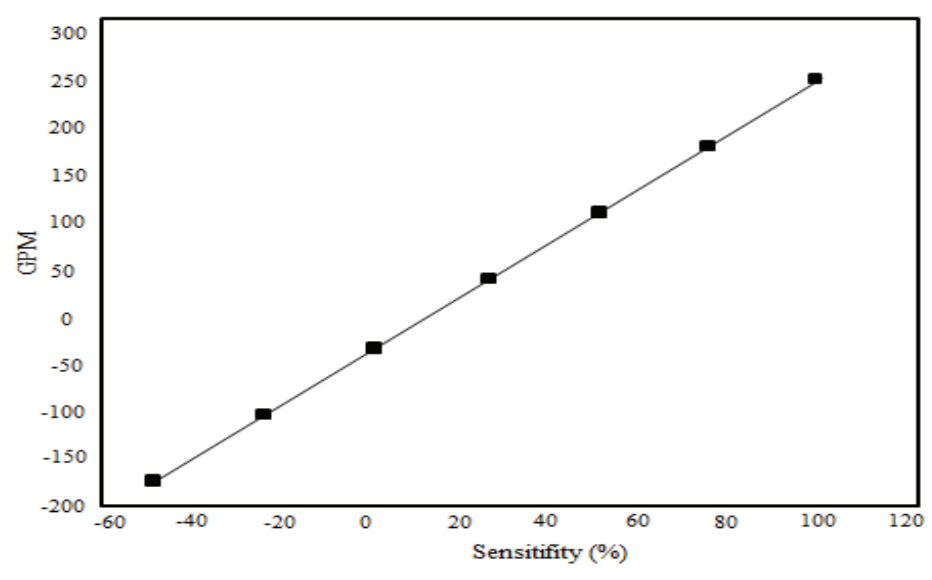

Figure 7. Effect of sales to GPM.

\section{Economic Analysis as the Effect of Sales to Profitability}

Effect of sales on profitability is shown in Figure 8. The effect of sales is made from the sensitivity of the estimated value (-50-120\%). Sales have an influence on project profits. The maximum profit of the project can be achieved when the sales value has a sensitivity of $100 \%$ of the estimated value of the sales, and the minimum profit limit the project can achieve is $25 \%$ of the estimated value of the sale. If the sales are less than $25 \%$, the project may fail.

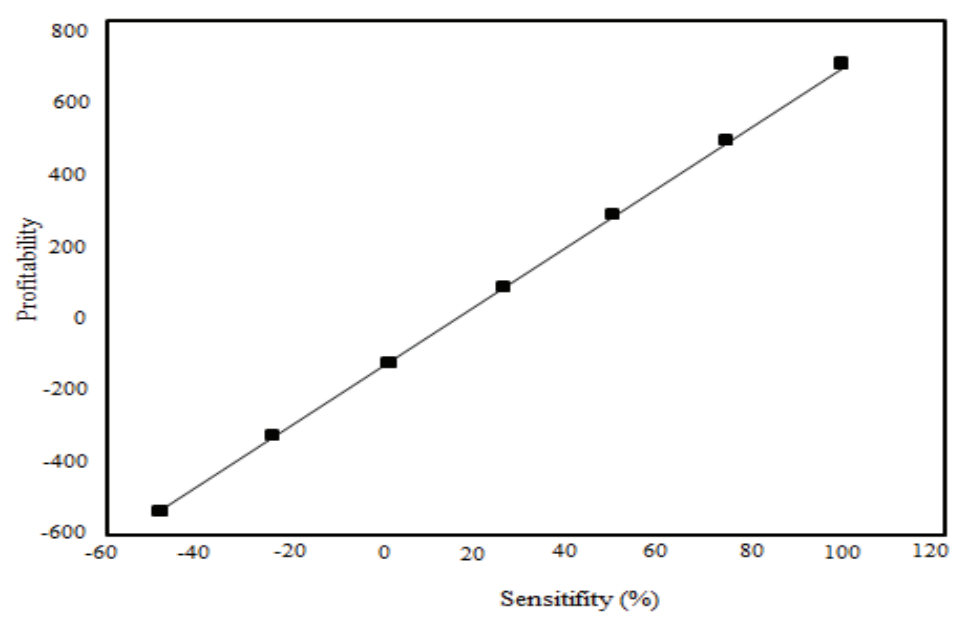

Figure 8. Effect of sales on profitability. 


\section{Analysis Condition to Make the Success Production}

Engineering analysis confirmed that this project is promising. Based on the mass balance of raw materials and products, the production process can be done in a small-scale industry (Nandiyanto et al., 2018). The main reason strengthening this argument is the conditions for the availability of parts and supporting components for assembling sieve shaker in the market.

Engineering analysis also confirmed simple plant design since there is no need for complex utility systems, informing that project can be developed without specific limitation of the place (such as near with the river, etc.). However, the better place for this project is near the transportation access area for distributing the raw materials and products.

The first cost analysis to determine profitability performance is the TIC. Based on the above assumptions, to produce 6000 products, TIC is less than 38,304 USD. This is used mostly for systems, including assembling space, storage, and computerization. This lower cost can be obtained because all materials are commercially available, and all production steps including the assembly process can be carried out in the small-scale area.

The value of GPM is obtained by deviating sales and raw material prices without considering other factors showing more than 51.95 USD per pack. Selling 6000 products per y can generate GPM 8,571,428 USD per y. Although GPM shows huge per y, GPM analysis cannot be used directly to determine whether a project is feasible or not. Additional project factors must be added to confirm realistic profitability conditions.

To get a realistic economic analysis, additional calculation of several factors of the project is required (including utility, calculation of total investment costs, and labor) (Machmud et al., 2019). As shown in Figure 2, after adding these factors, the cost analysis on all economic parameters shows a positive value, indicating a good opportunity to produce this product (Nandiyanto \& Ragadhita, 2019). Detailed information can be seen as follows:

a. The BEP analysis shows that the minimum processing cycle is 73 processes, 1640 products per y (more than 135 products per month). Compared to the engineering analysis, one process cycle (to assemble products) takes $2 \mathrm{~h}$. Then, because a one-y project contains $300 \mathrm{~d}$ (assuming holidays are non-day production), the maximum amount of production per y is 6,000 processing cycles. Thus, the BEP analysis shows that the current project will be profitable because the minimum BEP value has passed.

b. Analysis of the profit to sales and TIC shows excellent results. $100 \%$ of production capacity can generate profit-to-sales and profit-to-TIC of more than 80 and $721 \%$, respectively.

c. The detailed CNPV curve shows a positive value, even though the initial y is negative. However, after passing more than $2 \mathrm{y}$ of the project (for $100 \%$ of production capacity), CNPV showed a positive gradient, indicating that the project was profitable. The final CNPV and TIC ratio in $100 \%$ of production capacity is more than $90 \%$.

d. The results of GPM, BEP, sales profit, and TIC, as well as CNPV, confirmed the positive results, indicating that this project seems to attract industrial investors. However, to increase interest, there are several considerations.

1) Sales. Project must be absolutely sure that the product can be absorbed by the market. Otherwise, it will be difficult to run the project.

2) Production capacity. This consideration can be made only if there is a large market for adsorbing products. The increases in the level of production have a great impact on the obtainment of higher profits. However, this analysis must be done carefully because the increases in the production capacity have a direct correlation to the increases in other elements, such as raw material, labor cost, and utility cost. Thus, further feasibility studies must be conducted.

3) Corporate social responsibility (CSR) of a company or government. CSR is related to social and political conditions (Nandiyanto, 2018).

4) Join project with a supplier or manufacturer company for raw materials. This method can reduce the cost of raw materials, especially for shipping and handling costs. Indeed, this can have a great positive impact on profits. 


\section{Analysis of the Effectiveness of the Sieve Test Machine in the Teaching Process for Students with Visual Impairments}

Students with visual impairments are one of the students with special needs. They have barriers in the learning process, so they need special education and services (Maryanti et al., 2020b). Students with visual impairments optimize auditory and tactile functions in the learning process. In order for the learning process to run effectively, learning methods and media must be tailored to the needs of students (Maryanti et al., 2021b). One of them is the learning process about particle size. Students with visual impairments have problems understanding and differentiating particles. They study particle size through the sense of touch. One of the tools used in learning to separate particle sizes is the sieve test. However, students with visual impairments have difficulty using this tool. Therefore, it takes innovation and modification of the sieve test tool to suit the needs of students. Making a sieve test device automatically and equipped with braille letters on each sieve container has the benefit of making it easier for students in the learning process to distinguish particle sizes. The sieve test machine is made automatically using a machine to make it easier for students to use it and to save time and energy, because when a student uses a manual sieve test, he has difficulty arranging the sieve and shaking it, so that it will mess up the particles inside. Students with visual impairments have difficulty using complex tools (Maryanti et al., 2020c). The braille letters on each sieve container make it easy for students to read the particle size in the container. The sieve test is a learning medium that makes it easier for students with visual impairments to understand particle size material, especially in sizes 34,60 , $100,150,200$, and $250 \mu \mathrm{m}$. This is because students with special needs have difficulty understanding something abstract and complex (Maryanti et al., 2020d), especially for students with visual impairments. The sieve test learning media innovation using an automatic machine equipped with braille letters makes it easier for students to understand the particle size being taught. Learning media that are concrete and in accordance with the needs of students make it easier for students to understand the learning material being taught (Maryanti et al., 2020c). In addition, learning media at low prices make it easier for educators and students to be able to obtain and own these media to be used in the learning process.

\section{CONCLUSION}

The production of low-cost sieve shaker for student with visual impairment has been evaluated from engineering and economic feasibility studies. Based on the above analysis, this project is prospective from engineering point of view. The analysis of the cost of economic parameters also presents positive values, giving information about the profitability of the project. To be more profitable, there are at least four considerations: certainty of the need for this apparatus in the market, understanding production capacity, implementing CSR, and joining production with suppliers or producers of raw materials. In addition, because this research is the first analysis in the feasibility study, all economic analyses are done for $20 \mathrm{y}$ of production. Analysis of the teaching process: this tool has benefits for students with visual impairments in understanding material about particle size. The innovation of tools using automatic machines makes it easier for students to separate particle sizes, so that it is time-effective and efficient. Meanwhile, the innovation of adding braille letters to the filter sieve makes it easier for students with visual impairments to determine the size of the particles inside it. Media that are concrete, simple, and according to student needs make it easier for students to understand the material being taught. 


\section{REFERENCES}

Hierl, T., Kruber, D., Doerfler, H.M., Huempfner-Hierl, H. \& Krause, M. 2019. Computer-aided versus conventional planning in orbital traumatology using preformed meshes: development of a new workflow. Journal of Oral and Maxillofacial Surgery. 77 (8): 1663-1672.

Berry, A., Rodriguez, E. \& Sandee, H. 2001. Small and medium enterprise dynamics in Indonesia. Bulletin of Indonesian Economic Studies. 37 (3): 363-384.

Harris, L.M. 2008. Water rich, resource poor: intersections of gender, poverty, and vulnerability in newly irrigated areas of southeastern Turkey. World Development. 36 (12): 2643-2662.

Qi, F., Heindel, T.J. \& Wright, M.M. 2017. Numerical study of particle mixing in a lab-scale screw mixer using the discrete element method. Powder technology 308: 334-345.

Nandiyanto, A.B.D., Sofiani, D., Permatasari, N., Sucahya, T.N., Wiryani, A.S., Purnamasari, A., Rusli, A. \& Prima, E.C. 2016. Photodecomposition profile of organic material during the partial solar eclipse of 9 march 2016 and its correlation with organic material concentration and photocatalyst amount. Indonesian Journal of Science and Technology. 1(2): 132-155.

Nandiyanto, A.B.D., Putra, Z.A., Andika, R., Bilad, M.R., Kurniawan, T., Zulhijah, R. \& Hamidah, I. (2017). Porous activated carbon particles from rice straw waste and their adsorption properties. Journal of Engineering Science and Technology. 12 (8): 1-11.

Guarnieri, M. 2018. An historical survey on light technologies. IEEE Access. 6: 25881-25897.

Garrettt, D.E. 2012. Chemical Engineering Economics. New York: Van Nostrand Reinhold.

Nandiyanto, A.B.D. 2018. Cost analysis and economic evaluation for the fabrication of activated carbon and silica particles from rice straw waste. Journal of Engineering, Science, and Technology. 13 (6): 1523-1539.

Nandiyanto, A.B.D., Andika, R., Aziz, M. \& Riza, L.S. 2018. Working volume and milling time on the product size/morphology, product yield, and electricity consumption in the ball-milling process of organic material. Indonesian Journal of Science and Technology. 3 (2): 82-94.

Nandiyanto, A.B.D., Ragadhita, R., Maulana, A. \& Abdullah, A. 2018. Feasibility study on the production of biogas in dairy farming. IOP Conference Series: Material Science and Engineering. 288 (1): 012024.

Machmud, A., Ahman, E., Dirgantari, P.D., Waspada, I. \& Nandiyanto, A.B.D. 2019. Data envelopment analysis: The efficiency study of food industry in Indonesia. Journal of Engineering, Science, and Technology. 14 (1): 479-488.

Nandiyanto, A.B.D. \& Ragadhita, R. 2019. Feasibility study in the production of zinc imidazole framework particles. Journal of Engineering Research. 7: 36-49.

Maryanti, R., Nandiyanto, A. B. D., Hufad, A. \& Sunardi, S. 2021a. Science education for students with special needs in Indonesia: From definition, systematic review, education system, to curriculum. Indonesian Journal of Community and Special Needs Education, 1(1): 1-8.

Maryanti, R., Hufad, A. \& Sunardi, S. Nandiyanto, A. B. D. \& Manullang, T.I.B. 2020a. Understanding Coronavirus (COVID-19) as a Small Particle to Students with Special Needs Rina Maryantil, Achmad Hufad1, Sunardi1, Asep Bayu Dani Nandiyanto2,*, Tryastuti Irawati Belliny Manullang1. Horizon, 2(1): 121-130.

Rusyani, E., Maryanti, R., Utami, Y. T. \& Pratama, T. Y. 2021. Teaching Science In Plant Structure For Student With Hearing Impairments. Journal of Engineering Science and Technology, 16(2): 1577-1587. 
Maryanti, R., Hufad, A., Sunardi, S., Nandiyanto, A. B. D. \& Al-Obaidi, A. S. M. 2020b. Understanding covid-19 particle contagion through aerosol droplets for students with special needs. Journal of Engineering Science and Technology, 15(3): 1909-1920.

Maryanti, R., Hufad, A., Nandiyanto, A. B. D \& Tukimin, S. 2021b. Teaching the corrosion of iron particles in saline water to students with special needs. Journal of Engineering Science and Technology, 16(1): 601611.

Maryanti, R., Hufad, A., Tukimin, S., Nandiyanto, A. B. D. \& Manullang, T. I. B. 2020c. The importance of teaching viscosity using experimental demonstration from daily products on learning process especially for students with special needs. Journal of Engineering Science and Technology, 15: 19-29.

Maryanti, R., Nandiyanto, A. B. D., Manullang, T. I. B., Hufad, A. \& Sunardi. 2020d. Adsorption of Dye on Carbon Microparticles: Physicochemical Properties during Adsorption, Adsorption Isotherm and Education for Students with Special Needs. Sains Malaysiana, 49(12): 2949-2960.

Nurdiana, A., Astuti, L., Dewi, R.P., Ragadhita, R., Nandiyanto, A.B.D., \& Kurniawan, T. (2022). Technoeconomic analysis on the production of zinc sulfide nanoparticles by microwave irradiation method. ASEAN Journal of Science and Engineering, 2(2): 143-156.

Elia, S.H., Maharani, B.S., Yustia, I., Girsang, G.C.S., Nandiyanto, A.B.D., \& Kurniawan, T. (2023). Techno-economic evaluation of hyaluronic acid production through extraction method using yellowfin tuna eyeball. ASEAN Journal of Science and Engineering, 3(1): 1-10. 